Editorial

\title{
American and British administration legacy in Iraq: civilian deaths and development of diseases
}

Volume I Issue I - 2014

\section{Introduction}

The aim of Iraq invasion in 2003 by the United States and Britain administrations was to find "weapons of mass destruction", which turned to be completely untrue. The hidden agenda may range between revenge, financial gains and hatred, among others. What is depressing is that after 11years of invasion, the detrimental effect of this unjust war against civilian population of Iraq is mounting. In this brief editorial, I will summarize two aspects related to this invasion: 1. Casualties of civilians and 2. Deterioration of Iraqi population health.

\section{Casualties of civilians}

Burnham et al. ${ }^{1}$ interviewed several Iraqi families and estimated that between March 18, 2003 and June 2006, about 655,000 Iraqis died as a consequence of the American/British administration invasion. ${ }^{1}$ An earlier estimate of causalities reported in 2004 indicated about 112,000 deaths. ${ }^{1,2}$ According to the authors, these estimates of post-invasion represent a doubling of the baseline mortality rate which constitutes a humanitarian emergency "Sphere project". ${ }^{1}$ An up-dated study which collected data from 2000 randomly selected households in 100 geographical clusters distributed across Iraq's 18 govemorates between 2003-2011, estimated casualties due to the conflict at 405,000 with $95 \%$ confidence. $^{3}$ The authors also suggested that this may under-estimate the numbers of death because more than 1.1 million Iraqis were living in camps and displaced elsewhere who were not included in the survey. American/British forces caused higher total causalities in women and children between 2003-2008 period with half of disabled adults were women and more than $15 \%$ of the disabled were children under age 10, due to air attacks and the use of heavy air power. ${ }^{4}$

Suicide bombing is another form of killing, a phenomenon that was unfamiliar to Iraqis before the invasion and was brought upon by the invasion. Hicks et al. ${ }^{4}$ reported almost 43,000 casualties due to suicide bombings among Iraqi civilians, between the years 2003$2010 .^{4}$

\section{Deterioration of Iraqi population health}

It is clear that health status has been dramatically deteriorated in Iraq after the invasion. Many Iraqi civilians were injured or became ill due to damage of the health-supporting infrastructure of the country. ${ }^{5}$ More than 400 Iraqi physicians, who left the country due to violence, reported a great decline in health services in Iraq between the years 2003-2006. ${ }^{6}$ The number of deaths from cardiovascular conditions, cancer, chronic illness, and infant deaths rose dramatically and significantly after the invasion. ${ }^{1}$ Among the chronic illness is osteomyelitis that affected many Iraqi civilians, who in addition developed multidrug resistant to the bacterial infection. ${ }^{7}$ Further, rectum and colon injuries were increased. ${ }^{8}$ An estimated 1.4 million Iraqis became refugees in neighboring countries as a result of the American/British administration invasion, and most of them suffer
Azzam A Maghazachi
Department of Physiology, University of Oslo, Oslo, Norway

Correspondence: Azzam A Maghazachi, Department of Physiology, Institute of Basic Medical Sciences, University of Oslo, Oslo, Norway, Tel 47-228-5I2-03, Fax 47-228-512-79, Email azzammaghazachi@yahoo.com

Received: April 25, 2014| Published: April 28, 2014

from hypertension, musculoskeletal disorders and neurological diseases. $^{9-11}$

Bladder cancer became prevalent in Iraqi males and females post invasion. p53 is a tumor suppresser gene that functions to regulate bladder cancer. Mutations that occur in this gene result in the development of bladder cancer. Al-Kashwan et al. ${ }^{12}$ examined the effects of exposure to the hazardous pollution on p53 mutations. ${ }^{12}$ They reported frame shift mutations in TP53 in Iraqi bladder cancer patients which were higher in deep invasive tumors than superficially invasive tumors due to hazardous environmental pollution occurred as a consequence of bombings with untraditional weapons by the invading forces.

An additional setback is the reluctant of patients to visit their doctors in their war torn country. This was reflected by statements made by Iraqi refugee women in the USA who indicated that the unsafe situation in Iraq post invasion impeded them from visiting physicians. ${ }^{13}$ Further, most Iraqi refugee women suffer emotional trauma as a consequence to the invasion that left behind a destroyed and unsafe country, where militia groups control most of the country and its government offices.

\section{Conclusions}

Many articles described the effects of the American/British administration invasion of Iraq on the health of the troops involved. However, few dealt with the devastating effects on the real victims, which is the topic of this editorial. The death toll continues to rise in Iraq, which could be close to one million by the end of this year. This is due to the lack of security and the control of militias on every aspect of life in the present Iraq. It is a shame for us representing the medical community to call the unjust war in Iraq as "Iraqi freedom". This war brought destruction, diseases and resulted in the death and dispersed of more than 5 million Iraqi civilians. Whereas we try every day to come up with drugs to treat illnesses, one bomb drops on any part of the world could result in number of deaths far exceeds what the 
medical doctors and other health professionals can cure in one year The invasion of Iraq resulted in the deadliest international tragedy which is of grave concern to everyone. ${ }^{1}$

\section{Acknowledgements}

None.

\section{Conflicts of interest}

Author declares there are no conflicts of interest.

\section{Funding}

None.

\section{References}

1. Burnham G, Lafta R, Doocy S, et al. Mortality after the 2003 invasion of Iraq:a cross-sectional clusters sample survey. Lancet. 2006;368(9545):1421-1428

2. Roberts L, Lafta R, Garfield R, et al. Mortality before and after the 2003 invasion of Iraq:cluster sample survey. Lancet. 2004;364(9448):18571864.

3. Hagopian A, Flaxman AD, Takaro TK, et al. Mortality in Iraq associated with the 2003-2011 war and occupation:findings from a national cluster sample survey by the university collaborative Iraq Mortality Study. PLOS Med. 2013;10(10):e1001533.

4. Hicks MH, Dardagan H, Guerrero Serdan G, et al. Violent deaths of Iraqi civilians, 2003-2008:analysis by perpetrator, weapon, time, and location. PLOS Med. 2011;8(2):e1000415.
5. Levy BS, Sidel VW (2013) Adverse health consequences of the Iraq war. Lancet. 2013;381(9870):949-958.

6. Burnham G, Malik S, Al-Shibli AS, et al. Understanding the impact of conflict on health services in Iraq:information from 401 Iraqi refugee doctors in Jordan. Int J Health Plann Manag. 2012;27(1):e51-64.

7. Murphy RA, Ronat JB, Fakhri RM, et al. Multidrug-resistant chronic osteomyelitis complicating war injury in Iraqi civilians. J Trauma. 2011;71(1):252-254.

8. Steele SR, Wolcott KE, Mullenix PS, et al. Colon and rectal injuries during operation Iraqi freedom:are there any changing trends in management or outcome? Dis Colon Rectum. 2007;50(6):870-877.

9. Doocy S, Sirois A, Anderson J, et al. Food security and humanitarian assistance among displaced Iraqi populations in Jordan and Syria. SocSci Med. 2012;72(2):273-282.

10. Doocy S, Sirois A, Tileva M, et al. Chronic disease and disability among Iraqi populations displaced in Jordan and Syria. Int $J$ Health Plann Manage. 2013;28(1):e1-e12.

11. Mateen FJ, Carone M, Nyce S, et al. Neurological disorders in Iraqi refugees in Jordan:data from the United Nations Refugee Assistance Information System. J Neurol. 2013;259(4):694-701.

12. Al-Kashwan TA, Houshmand M, Al-Janabi A, et al. Specificmutational patterns of p53 gene in bladder transitional cell carcinoma among a group of Iraqi patients exposed to war environmental hazards. BMC Res Notes. 2012;5:466.

13. Saadi A, Bond B, Percac-Lima S. Perspectives on preventive health care and barriers to breast cancer screening among Iraqi women refugees. $J$ Immigr Minor Health. 2012;14(4):633-639. 